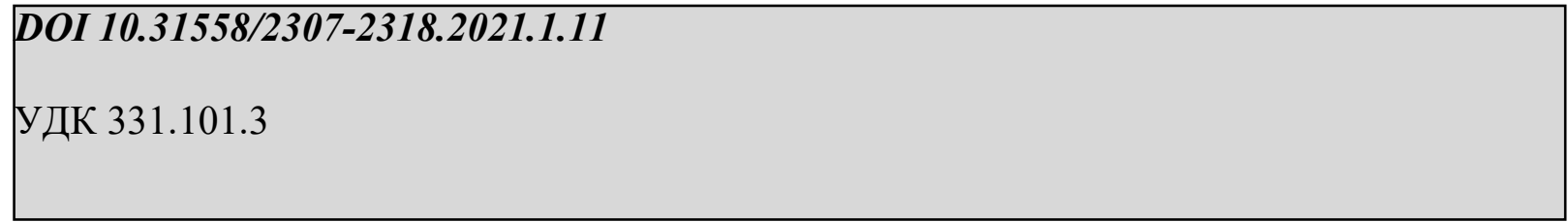

Таранич О.В.,

к.е.н., доцент, доцент кафедри менеджменту та поведінкової економіки, Донецький національний університет імені Василя Стуса

ORCID: 0000-0002-7859-8706

o.taranych@donnu.edu.ua

Вісіцька Д. О.,

здобувач вищої освіти, Донецький національний університет імені Василя Стуса visitska.d@donnu.edu.ua

\title{
МОТИВАЦІЯ ДЕРЖАВНИХ СЛУЖБОВЦІВ У СИСТЕМІ АДМІНІСТРАТИВНОГО МЕНЕДЖМЕНТУ
}

У досліджені подано інформацію про систему мотиващіі в адміністративному менеджменті та їі роль $і$ значення в умовах сучасного господарювання, розглянуто основні теорії, які стали основою для побудови сьогоднішнього мотиваційного механізму, використання методів заохочення на прикладі державних службовців України та розгляд іноземного досвіду щзодо мотиваційного забезпечення. Для досягнення поставленої мети, при вирішенні завдань було використано загальнонаукові та спеціальні методи теоретичних й емпіричних досліджень: огляд наукової літератури за темою дослідження, термінологічний, статистичний аналіз, метод порівняльного аналізу й синтезу.

Ключові слова: мотивація, методи мотивачії, стимулювання, адміністративний менеджмент, державний службовець.

Табл. -1, рис. -2 , літ. -5 .

Вступ. Мотивація відіграє надзвичайно важливу роль в адміністративному плануванні підприємства, адже в держаному управлінні досяжні цілі залежать від рівня стимулювання працівників. Створення належної мотиваційної системи здатне спонукати працівників до ефективної праці, а підприємство до зростання свого економічного потенціалу. Важливим фактором повинна стати особиста зацікавленість працівників, яка заснована на задоволенні власних соціальних і фізіологічних потреб.

Аналіз останніх досліджень та публікацій. Тематика мотивації та стимулювання на посадах державних службовців привертала і досі привертає достатню увагу сучасних науковців, таких як: Л. Артеменко, С. Білорусов, Н. Богданова, І. Гліва, П. Ігнатьєв, Р. Гриффіна, Н. Гончарук, А. Єгоршина, С. Озірська, О. Єськова, С. Занюк, В. Соловйова, Т. Соколова, В. Цвєтков, Н. Стецюк, Г. Чернецька та інші.

Метою дослідження $\epsilon$ аналіз мотивації державних службовців в системі адміністративного менеджменту в Україні та розгляд іноземного досвіду їх стимулювання.

Основна частина. Адміністративний менеджмент характеризується мінімальним об'ємом мотиваційної діяльності керівництва та його апарату, i, безумовно, носить адміністративно-організаційний характер із прямим централізованим впливом суб'єкта на об'єкт управління. У державному управлінні досяжні цілі прямо залежать від належного рівня стимулювання працівників, адже за умов правильного розроблення мотиваційної моделі працівники самореалізують свої внутрішні спонукання, а також повністю або 
частково задовольняють власні потреби в первинній, вторинній, ближній, дальній мотивації.

Відповідно, мотивація - це довготерміновий процес спонукання працівників до ефективної трудової діяльності для створення відповідних мотиваційних систем і розвитку трудового потенціалу організації на цій основі. До даних дій працівника спонукають бажання, потреби, стимули та інтереси. Тому керівництво не повинне ігнорувати дані чинники для успішного розвитку підприємства. Як правило, одним із головних завдань мотивації праці є підвищення віддачі від людського капіталу на підприємстві, досягнення ефективності та продуктивності діяльності власного персоналу.

Основна мета процесу мотивації - це підвищення результативності та прибутковості підприємства від використання людських ресурсів. Мотивація та стимулювання в адміністративному менеджменті - це методи управління працею, які спрямовані на зміну існуючої системи на підприємстві та ії закріплення. Відповідно, стимулювання працівників - це певний створений механізм, при якому активна трудова діяльність дає зафіксовані результати, стає значимою умовою задоволення потреб персоналу, тим самим, формуючи у нього мотиви праці.

Основна мета процесу стимулювання - уміння завжди зацікавлювати більш краще працювати та продуктивніше, ніж це обумовлено трудовими відносинами. Для цього необхідно вмотивувати кожного працівника індивідуально з огляду на його персональні потреби й цінності. Відповідно, до даної системи відноситься гідна оплата праці, забезпечення гідних умов праці для стійкого відновлення трудової енергії, ентузіазму, завзятості, робочої сили, при забезпеченні працівників житлом, послугами охорони здоров'я, трудового навчання й освіти.

Великі філософи вважали, що мотивація є джерелом праці людства. Саме на визначення цього поняття потрібно було десятки тисяч років, адже, інтерес до «стимулювання» виник ще до появи науки управління. Еволюція вчень про сутність мотивації праці має достатньо довгий шлях. Проблеми людських відчуттів, як і шляхів підвищення продуктивності праці шляхом мотивації починали розглядали ще великі мислителі античності - Аристотель, Геракліт, Демокріт, Лукрецій, Платон та Сократ. Вагомий внесок в історію розвитку мотивації трудової діяльності працівників зробили такі класики, як А.Сміт, Ф.Тейлор, А.Маслоу. А.Сміт - класик англійської політичної економії, який у XVIII ст. зробив перші спроби до усвідомлення сутності мотивів людини і того, що саме спонукає іiі до праці. Він ототожнював особистісні економічні інтереси людини 3 головними мотивами діяльності, 3 прагненням до максимальної вигоди й природним бажання людей покращити свій добробут [1].

Багато пізніше американський психолог Абрагам Маслоу одним із перших дослідив складний світ потреб робітників і їх вплив на трудову мотивацію, та створив ієрархію потреб. Його теорія значно розширила наукове розуміння основ, які лежать в основі людських інтересів і професійних дій. Основна ідея Маслоу - принцип відносної пріоритетності мотивів, згідно із якими потреби нижчих рівнів вимагають первинного та негайного задоволення, вони визначають поведінку людини частіше, ніж соціальні потреби та потреби найвищого рівня(табл. 1).

Елтон Мейо у соціопсихічній теорії мотивації стверджував, що ефективними $\epsilon$ нематеріальні стимули та мотиви, які передбачають сприйняття індивіда групою й заохочення його дій іншими людьми.

Теорія мотивації досягнення успіхів Д. МакКлелланда, Д. Аткінсона й Х. Хекхаузена базується на висновку, що досягнення успіху пов'язане з самим мотивом успіху й мотивом 
уникнення невдач. Основна увага теорії зосереджена на поведінці людей, які ставлять перед собою позитивну ціль і активно діють, щоб ії досягнути, й навпаки.

Таблиця 1 - Класифікація мотивів за А. Маслоу

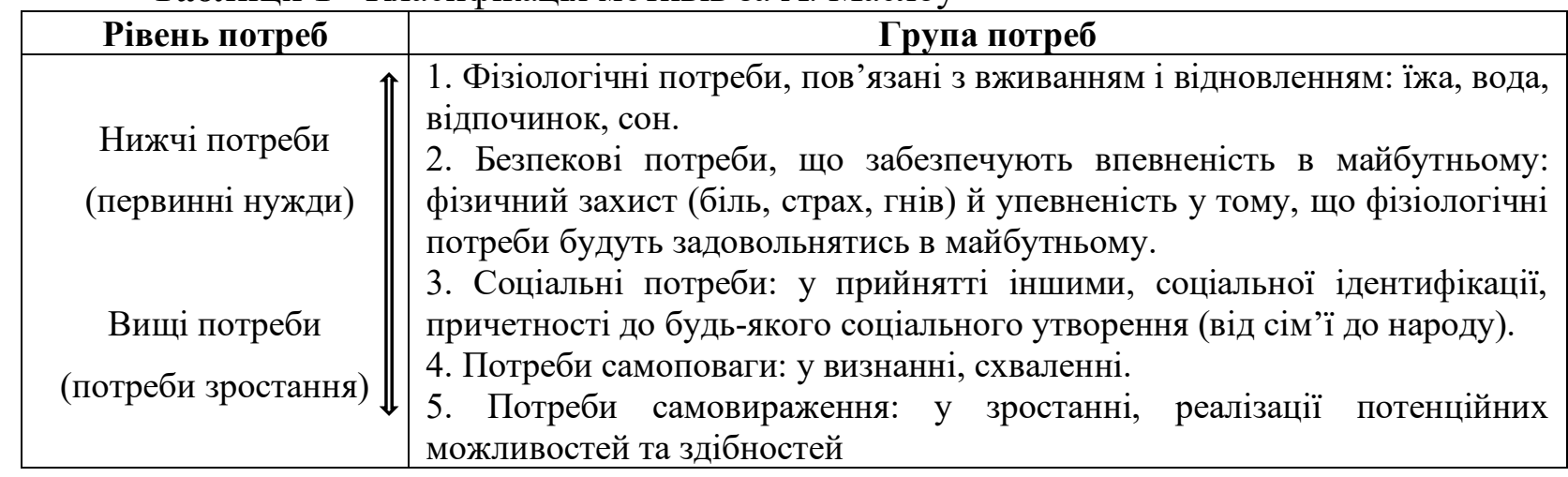

Не менш відома теорія сподівань (модель Врума). На думку Врума, мотивація - це результат дії трьох факторів: бажання особи отримати винагороду (валентність), сподівання, що докладені зусилля принесуть успішний результат та досягнення цілі буде винагороджено. Виходячи із вище описаних теорій, варто зауважити, розглянуті теорії мотивації праці $є$ та були основою для побудови сучасного мотиваційного механізму та моделей, із сукупністю підходів і практичних намірів, які містять певні теоретичні положення і погляди.

Основне стратегічне завдання організації будь-якої сфери галузі - це побудова ефективної системи мотивації, що здатна впливати на продуктивність виконання трудової діяльності й на конкурентоспроможність корпорації в ринкових умовах. Як правило, вірно налагоджена мотиваційна система забезпечує:

- отримання єдиної узгодженої системи мотивації на усіх рівнях: керівництво компанії, менеджмент середньої ланки, рядові співробітники;

- $\quad$ максимальне залучення персоналу в роботу для реалізації стратегій та отримання високого прибутку підприємства;

- встановлення економічно-обгрунтованої системи преміювання й справедливого рівня оплати праці, нарахування бонусів та інших матеріальних заохочень;

- $\quad$ встановлення нормативів й крайніх значень показників для співробітників;

- $\quad$ доцільне планування витрат на оплату праці та забезпечення їх економії;

- подальший самостійний розвиток систем мотивації та стимулювання HRвідділом, відповідно до потреб підприємства;

- забезпечення конкурентоспроможності підприємства як роботодавця на ринку праці за рахунок релевантної ринковим тенденціям системи оплати;

- збереження зайнятості персоналу, зменшення плинності кадрів й підвищення їх конкурентоспроможності на ринку праці;

- створення сприятливих, зручних й безпечних умов праці;

- $\quad$ можливості професійного та кар'єрного зростання для усіх категорій працівників.

Сучасний розвиток мотиваційної системи у адміністративному менеджменті характеризується великою кількістю ефективних методів стимулювання трудової діяльності. Безперечно, методи мотивації та стимулювання працівників на підприємстві це сукупність певних управлінських впливів на персонал 3 метою отримання максимального прибутку та досягнення соціальної вигоди підприємства. 
На сьогоднішній день, найбільш поширеними $є$ використання адміністративних, економічних та соціально-психологічних способів заохочення.

Матеріальні методи - це прагнення певного рівня добробуту, достатку та стандарту життя, який реалізовується, як правило, через гідну оплату праці, систематичний диференційований облік видів і результатів праці, оплату за проїзд, пільги на харчування, медичне обслуговування тощо. Використання даного виду є досить ефективним, але в умовах сучасного господарювання, втрачає свою дієвість. Відповідно, нині працівники та керівники підприємств надають перевагу нематеріальним способам заохоченням так, як пріоритетами виступають просування по службі та кар'єрне зростання.

Нематеріальне стимулювання - це негрошове заохочення працівників, яке сприяє формуванню корпоративного духу адміністрації та сприятливих внутрішньо-організаційних відносин.

Соціально-психологічні методи грунтуються на врахуванні особливостей людей, культурних норм, цінностей та форм спілкування, i, як правило до них відносяться:

- забезпечення можливості працівниками надавати свої зауваження та пропозицій як з приводу покращення кадрової політики та соціально-трудових відносин, так і з питань управління виробництвом чи організацією в цілому;

- гуманізація праці, тобто покращення умов праці та збагачення іiї змістовності, створення раціонального режиму праці й відпочинку, встановлення вільного робочого графіку;

- залучення працівників до розв'язування ряду проблем підприємства (соціального характеру), тобто надання права голосу в управлінні;

- впровадження принципів корпоративної культури;

- усне й письмове вираження подяки працівнику керівником;

- схвалення й підтримка при виконанні різної важкості завдань;

- особисте й публічне визнання на загальних зборах колективу;

- забезпечення можливостей автономії в роботі та прийнятті рішень 3 метою реалізації себе на робочому місці.

Адміністративні методи мотивації - це методи прямого рішення із централізованим характером впливу суб'єкта на об'єкт, авторитарним стилем керівництва, що мають обов'язкову силу виконання. Даний метод заохочення орієнтований на такі мотиви поведінки, як свідома необхідність трудової дисципліни, відчуття боргу, цілеспрямоване бажання здійснювати трудову діяльність у певній організації й культура трудової діяльності.

Адміністративні методи мотивації вимагають від працівників націленості на результат, у разі не виконання якого, буде покарання у вигляді звільнення, здійснюється прямий вплив на волю людей через надання розпоряджень та обов'язковості їх виконання, вимагають постійного контролю, дотримання чіткої дисципліни та супроводжуються різними можливими покараннями (рис.1).

Організаційно-стабілізуючі методи адміністративного стимулювання - це правові акти та норми, що затверджені державними органами для обов'язкового їх виконання. До них відносяться: закони, укази, статути, правила, державні стандарти тощо.

Методи організаційного впливу, як правило, діють у внутрішньому середовищі компанії, тобто всередині й регламентують склад, зміст, взаємозв'язки усіх підсистем підприємства. Документи: регламентування, інструкції, організаційні схеми, нормування праці. Розпорядчі методи використовуються у процесі оперативного керівництва й використовуються у формі наказів i розпоряджень адміністративного складу. 
Дисциплінарні методи базуються на антистимулах, таких як страх перед звільненням, отримання штрафів, доган й інших видів покарань. Отже, адміністративні методи заохочень виходять 3 права керівництва виконання вимог підприємства щодо дотримання підлеглими правил трудової діяльності та дисципліни.

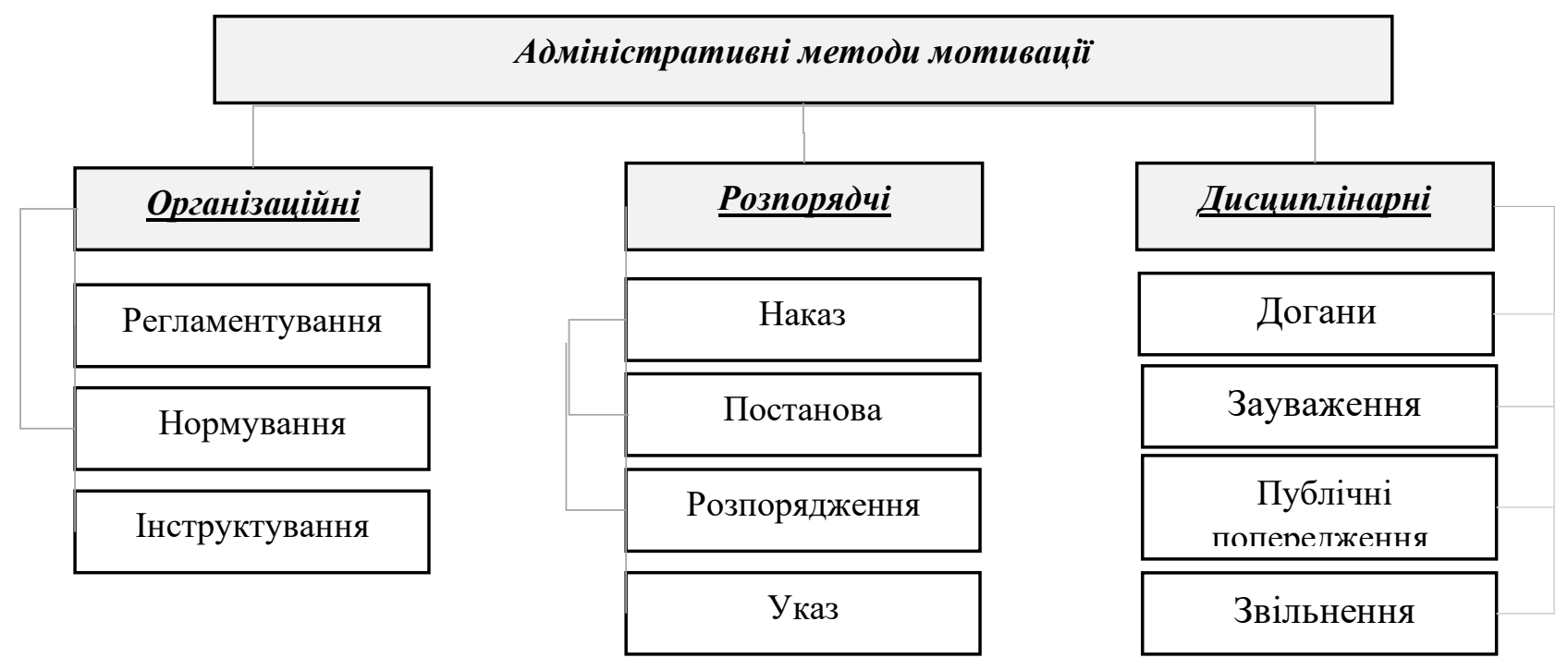

Рисунок 1. Адміністративні методи мотивації

Здійснивши аналіз зазначених складових компонентів методів матеріального й немонетизованого стимулювання на прикладі державних службовців України, можна стверджувати, що в основі їх цілеспрямованого управління лежить стратегія потреби та «мотиваційна сфера особистості».

В теперішній час Закон України № 889 «Про державну службу» для державних службовців $\epsilon$ базовим законодавчим актом щодо підвищення їх мотивації. Норми матеріального заохочення державних службовців закріплені в розділі 6 Закону. Вони визначають складові заробітної плати. Стаття 50 Закону зазначає: «Держава забезпечує достатній рівень оплати праці державних службовців для професійного виконання посадових обов'язків, заохочує їх до результативної, ефективної, доброчесної та ініціативної роботи» [2]. Складовими системи мотивації державного службовця в Україні являються матеріальне, нематеріальне та соціально-психологічне стимулювання до підвищення продуктивності праці даної групи фахівців (рис.2).

Відповідно, при задоволенні державними службовцями власних потреб вони стають джерелом розвитку їх як особистостей. I зворотньо, потреби державних службовців знаходяться в залежності від їх соціалізації та людського розвитку. Одночасне зростання особистості та соціалізації у суспільстві визначає рівень актуальних потреб, що яскраво підкреслює мотивацію до державно-суспільної праці, визначає прагнення з професійного розвитку на державних посадах [3].

На сьогодні існує певний ряд проблем у сфері адміністративного управління, що впливають на якість заміщення державних посад в Україні. До них варто віднести:

- формальний характер кадрових технологій, тобто низький рівень атестації державних службовців та неналежне формування кадрового резерву;

- відсутність постійного розвитку фахівців на посадах державних службовців;

- $\quad$ не має досвіду застосування системного підходу щодо формування кадрів;

- відсутність адміністративного планування на усіх етапах розвитку працівників. 


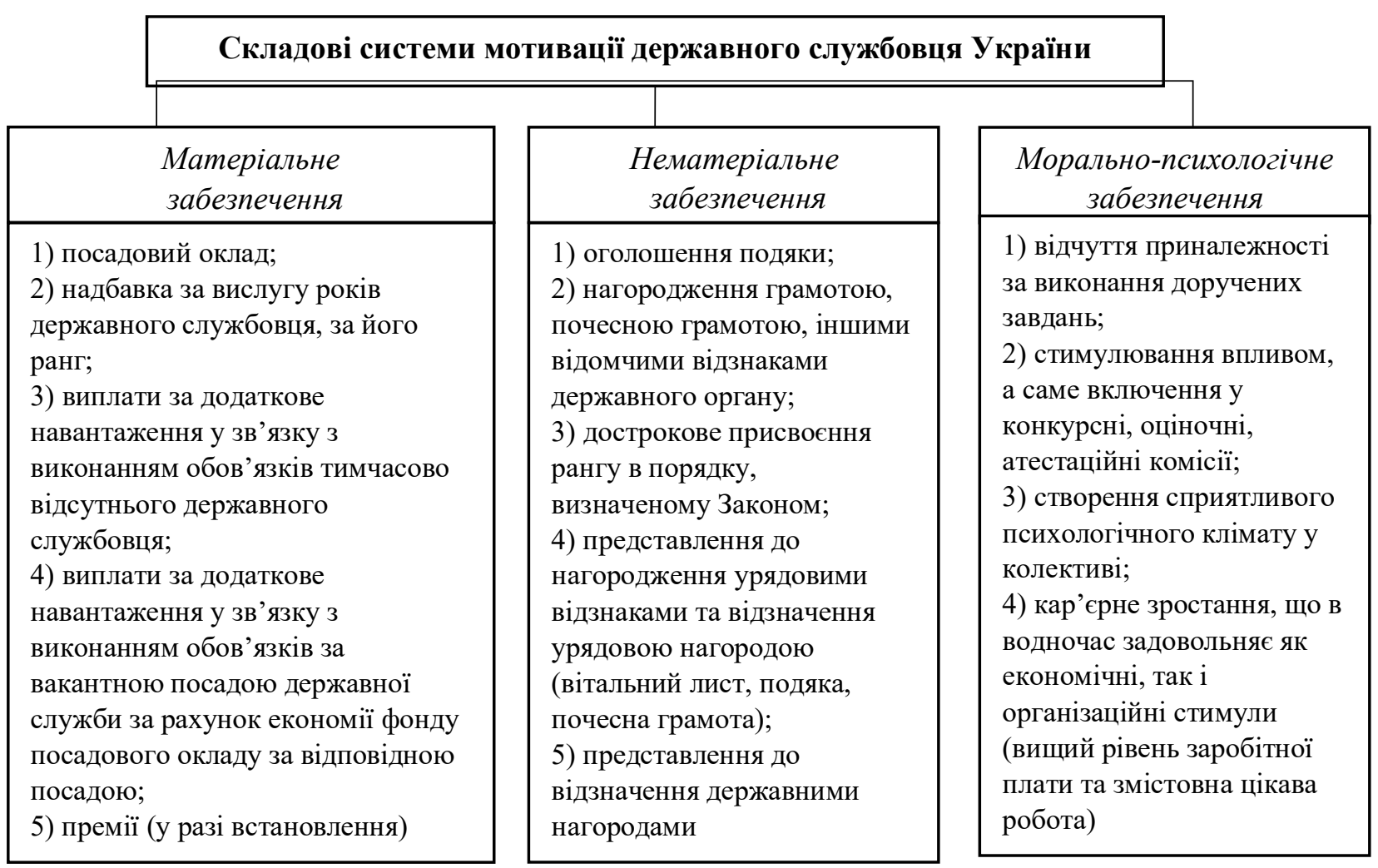

Рисунок 2. Складові системи мотивації державного службовця України

Оцінивши та розглянувши систему мотивації трудової діяльності на прикладі державних службовців в Україні, також варто взяти до уваги досвід зарубіжних країн щодо вдосконалення заохочення та стимулювання даних фахівців.

Як показує практика, накопичений світовий досвід допомагає сформувати належну систему мотивації праці на українських підприємствах, уникнути безліч недоліків та заздалегідь виявити можливі проблеми. На сьогоднішній день 3 усіх існуючих моделей найбільш ефективними, серед розвинених країн світу, є Сполучені Штати Америки, Німеччина, Франція й Японія.

Попередньо проведені адміністративні реформи у даних країнах позитивно вплинули на ключові елементи державної служби, що допомогло покращити систему матеріального стимулювання державних службовців, зробивши іiі більш гнучкою й результативною, та ефективніше функціонувати системі просування за заслугами. Відповідно, у розглянутих країнах високо розвинений менеджмент у сфері кар'єрного розвитку, а саме гнучка система поля діяльності, високий рівень іiі мобільності й можливостей просування на основі професійних досягнень.

Мотивація праці державної служби в США базується на принципах справедливої оплати за «рівну» працю, мобільності персоналу шляхом заохочення, навчання-стажування, соціально-культурних особливостях нації, тобто на досягненні успіху та на високому рівні економічного добробуту. Екс-президент США Клінтон та віце-президент Гір у 1993 році розпочали найбільшу в історії федерального правління управлінську реформу-ініціативу «Перебудова системи державного управління» 3 метою забезпечення більш ефективної роботи влади.

Американська модель, як правило, поділяється на кар'єрних державних службовців, що професійно просуваються по службі у відповідності із системою заохочень, та некар'єрних, які займають патронажні посади. Просування по службі здійснюється для 
більшості чиновників за системою заслуг - на конкурсних іспитах відбувається відбір кандидатів на підвищення в посаді, а також шляхом річної оцінки службової діяльності кандидатів. Кожна установа державної служби має власну програму службового просування. Якщо для певної посади бракує власних кандидатів, оголошується відкритий конкурс для цієї установи [4].

У рамках системи планування кар'єрного зростання діє дворічна програма CareerEntryProgram (CER), яка передбачає наявність високого коефіцієнта трудової діяльності та різні форми навчання (on-jobtraining).

Влада Сполучених Штатів Америки приділяє особливу увагу нематеріальній мотивації, а саме мобільності працівників шляхом заохочень та запровадженням гнучкого робочого графіку, такий підхід дозволяє службовцям набувати нові знання й навички, встановлювати налагодженні відносини із співробітниками інших органів та з'являється можливість розвитку особистості.

Американська модель оплати праці державних службовців являється конкурентоспроможною на ринку у порівнянні із приватними секторами й передбачає такі види матеріального забезпечення: заробітна плата - являє собою суму окладу та додаткової оплати за географічними регіонами, забезпечення у сфері медичного страхування та нарахування високих бонусів на охорону здоров'я.

На відміну від американської моделі, яка спирається на конкурентоспроможність кандидатів, в СС неодмінними передумовами суспільного консенсусу $\epsilon$ соціальна справедливість і солідарність. Свропейські школи менеджменту визначають, що найбільш оптимальною мотиваційною моделлю, у порівнянні з відомими в історії економічних вчень, $\epsilon$ гармонійна, гнучка комбінація прямого стимулювання праці та надання соціальних гарантій. Така модель одночасно забезпечує $\mathrm{i}$ економічний добробут, i виконання соціальних гарантій з боку держави.

Також особливою є німецька модель мотивації праці, яка базується на інтересах працівників, як вільних людей. В Німеччині основний наголос робиться на просуванні державною службою, використовується система кар'єрного зростання на базі досягнутих результатів. Не можна залишити поза увагою, що мотивація професіональної самореалізації відбувається на етапі навчання майбутніх спеціалістів. Такі програми передбачають передачу відповідних знань й досвіду, формування певного образу мислення, поведінки службовців відповідного рангу, на престиж професії та на їі ефективність. Як правило, тривалість навчання державних службовців, проходження стажування передбачають досить довгий період витрат часового ресурсу на вивчення реальної практики.

Система державної служби Німеччини має гнучку систему оплати праці, рівень якої залежить від робочого стажу, що базується на регресивному принципі та передбачає отримання бонусів, виходячи із результатів роботи державних органів. На рівень заробітної плати впливають такі фактори, як рівень освіти, рівень кваліфікації державного службовця та територіальне розміщення країни.

Структура заробітної плати державного службовця Німеччини включає:

1) оклад, що становить $85 \%$ сукупного доходу;

2) надбавку, встановлену для кожного рангу в залежності від сімейного становища й кількості дітей у сім'ї;

3) міністерську надбавку;

4) новорічні премії у розмірі місячного рівня заробітної платні;

5) відпускні в залежності від сімейного стану державного службовця; 
6) державні службовці, які працюють в свята, вихідні, вночі більш ніж 5 днів в тиждень, можуть отримати ще до 8 днів додатково до відпустки зі збереженням заробітної плати;

7) виплата до 50\% медичних витрат. При цьому інші 50\% медичних витрат державні службовці оплачують самостійно або за рахунок страхової.

На більшості підприємств Німеччини головним видом нематеріальної мотивації виступає соціальний пакет для найманих співробітників, тобто соціальне страхування. Воно містить норми пенсійного страхування за інвалідністю, за віком, у зв'язку зі смертю працівника (19,3\%); медичного страхування (від 13 до 14\%); страхування по догляду за хворим (1,7\%) й страхування від нещасного випадку (приблизно $1 \%$ ).

Найбільш гнучкою та ефективною моделлю виступає японська, так як японський персонал вважається найбільш відданим тій компанії чи підприємству, де працює. Їх відданість характеризується часом, жертовністю та зневагою до власних інтересів. Причинами цього явища: працівники твердо переконані у тому, що саме вони відповідальні за майбутнє компанії та надзвичайно важливі для неї, досить рідко беруть відпустки й відпочинок, адже вважають, що компанія має потребу в роботі та тим самим висловлять нелояльність фірм, через це спостерігається найнижчий у світі рівень втрат робочого часу та службовці завжди погоджуються понаднормово працювати без вагань: «треба - значить, треба».

Щодо матеріального забезпечення, то заробітна плата державного службовця у Японії має тарифну оплату праці й складається з тарифної ставки та надбавки до неї, близько 15\% місячної зарплатні складають надурочні роботи. Відповідно, додаються також премії за встановлення робочого часу на виконання надурочних робіт, які виплачуються 2 рази на місяць. Сучасна система оплати трудової діяльності заснована на таблиці посад і класів, що зафіксовані у відповідності до Закону про державних службовців. Органи влади також передбачають різні види соціальних виплат, як виплати на утримання дітей, транспортні, відпустки та лікувальні витрати.

На сьогоднішній день в Японії почали широко використовувати методи нематеріального стимулювання. Наприклад, можливості для державних службовців професійного, кар'єрного зростання, залучення працівників до певних гуртків чи об'єднань, створення тісних міжособистісних відносин. Керівництво японських органів державної служби дотримується норм неформального ділового спілкування зі співробітниками шляхом повсякденного спілкування, обміном привітаннями між підлеглими та керівним складом.

Французька модель мотивації трудової діяльності службовців включає в себе стратегічне планування, стимулювання конкуренції й гнучку систему оподаткування. Як правило, конкуренція є базисом французької моделі, яка визначає якість роботи з надання адмінпослуг, як задовольняються потреби населення та зменшуються накладні / виробничі витрати. Винятком $є$ те, що французька модель більше опирається на матеріальне стимулювання праці.

Перевагою французької моделі до мотивації праці державних службовців є відчутне стимулювання ефективності й якості праці, як фактор саморегуляції розміру фондів оплати праці. У разі виникнення тимчасових труднощів відбувається автоматичне скорочення фонду оплати праці, що дозволяє державним установам мінімізувати вплив кон'юнктурних змін. Така модель базується на широкій поінформованості фахівців про економічне становище сьогодення [5]. 
Розглянувши основний досвід провідних країн світу, можна зробити висновок, що кожна із моделей має національні особливості та особистісні підходи до мотивації й стимулювання державних службовців.

Висновки. Мотивація праці в адміністративному менеджменті $є$ найважливішим чинником у професійній діяльності, яке залучає працівників до ефективної праці для досягнення цілей підприємства та їх соціальної вигоди через задоволення потреб, цінностей й запитів кожного співробітника окремо. Як правило, побудова правильного стимулюючого середовища - стратегічне завдання організації.

Проведене дослідження щодо мотиваційного забезпечення державних службовців України дало змогу виявити, що рівень стимулювання працівників на даних посадах все ж таки знаходиться на належному рівні, органи влади використовують на практиці різні методи заохочень для підвищення продуктивності трудової діяльності. Але, у ході аналізу, було виявлено певні проблеми у даній сфері, як низька якість заміщення державних посад, неврахування індивідуальностей кожної особи та їх потреб.

Досвід зарубіжних країн допоможе сформувати належну систему мотивації праці на українських підприємствах, уникнути безліч недоліків та заздалегідь виявити можливі проблеми. Зроблено висновок, що найбільш ефективної моделі мотивування не існує, але кожна має ряд певних особливостей, які було б варто взяти до уваги. Відповідно, українським підприємствам потрібно проаналізувати усі основні характеристики відомих моделей, прийоми та особливості для досягнення власного соціального ефекту, отримання максимально високого прибутку та залучення персоналу до високопродуктивної діяльності.

Таким чином, обираючи ефективні методи мотивації та стимулювання, матеріальні чи нематеріальні, обов'язково слід враховувати потреби й інтереси підлеглих, їх переваги й недоліки індивідуально для кожного, щоб трудова діяльність була досить ефективною, методи заохочення мають бути надзвичайно цінними для виконавців. Адже формування ефективних механізмів мотивації та стимулювання працівників спрямовані на збереження зайнятості персоналу, справедливий розподіл доходів та оплати праці, забезпечення сприятливих та гідних умов праці, кар'єрного та професійного зростання, створення сприятливого мікроклімату у колективі та зворотного зв'язку.

Щодо перспектив подальшого дослідження, органам влади України варто здійснити аналіз, розробити механізми й методи щодо реформування системи посад державної служби на основі іноземного досвіду розвинених країн світу.

\section{СПИСОК ВИКОРИСТАНОЇ ЛІТЕРАТУРИ}

1. Бойко О.В. Організаційно-економічні аспекти мотивації трудової діяльності на підприємствах: автореф. дис. на здобуття наук. ступеня канд. екон. наук: спец. 08.06.01 «Економіка, організація і управління підприємствами» / О.В.Бойко. - К.: НАУ. -2019. - 20с.

2. Законодавство України. Офіційний портал Верховної Ради України. URL: https://www.rada.gov.ua/news/zak

3. Мотивація та заохочення державних службовців. URL: https://i.factor.ua/ukr/journals/ds/2018/december/issue-12/article-41307.html

4. Василенко И.А. Административно-государственное управление в странах Запада: США, Великобритания, Франция, Германия. - М.: Логос, 2018. - С.145.

5. Данюк В. М. Концептуальні особливості дослідження ефективності мотивації персоналу / В.М. Данюк // Вісник Східноукраїнського національного університету імені В. Даля. - 2016. - № 11 (105). - С.55-61. 
Таранич О.В., Висицкая Д. А.

\section{МОТИВАЦИЯ ГОСУДАРСТВЕННЫХ СЛУЖАЩИХ В СИСТЕМЕ АДМИНИСТРАТИВНОГО МЕНЕДЖМЕНТА}

В исследовании представлена информация о системе мотивации в административном менеджменте и ее роль и значение в условиях современного хозяйствования, рассмотрены основные теории, которые стали основой для построения сегодняшнего мотивационного механизма и использования методов поощрения на примере государственных служащих. Для достижения поставленной цели и решения задач в работе использовались общенаучные и специальные теоретические и эмпирические методы: анализ научной литературы по теме исследования, терминологический, статистический, метод сравнительного анализа и синтеза.

Ключевые слова: мотивация, методы мотивации, стимулирования, административный менеджмент, государственный служащий.

\section{Taranych O., Visitska D.}

\section{MOTIVATION OF PUBLIC OFFICERS IN THE ADMINISTRATIVE MANAGEMENT SYSTEM}

In the provides information about the system of motivation in administrative management and its role and significance in the conditions of modern business, considers the basic theories, which became the basis for building today's motivational mechanism and the use of incentive methods on the example of civil servants. To achieve this goal and solve problems, general scientific and special theoretical and empirical methods were used in the work: analysis of scientific literature on the research topic, terminologically, statistical, the method of comparative analysis and synthesis.

Keywords: motivation, methods of motivation, incentives, administrative management, civil servant 